\title{
COMMENT ON NICO KRISCH, “THE DECAY OF CONSENT: INTERNATIONAL LAW IN AN AGE OF GLOBAL PUBLIC GOODS"
}

\author{
Eyal Benvenisti* and George W. Downst
}

In his recent article 1 , Nico Krisch joins an increasing number of scholars who worry about the "turn toward nonconsensual structures" in international lawmaking. Although the article is primarily descriptive and does not set out to offer either a rigorous explanation or a normative assessment of this trend, Krisch does suggest that the trend "reflects the fact that the need for greater cooperation [at the global level] . . is not always, or not even typically, satisfied by international law." It also gives voice to the concern that the move to informal institutions "point[s] in the direction of more hierarchical forms of governance" that increasingly cater to a small number of powerful states, rather than to the traditional, broad, consent-based order.

Krisch juxtaposes this worry about emergence of a "the decay of consent" against two historical alternatives. The first is "the dominant narrative of the continuing rise and growth of international law in times of global interdependence. That narrative is common among international lawyers - whether they are sympathetic or hostile to the development - and is also widely shared among international relations scholars." While this camp may characterize writers of the mid-1990s, it has recently been largely overtaken by a new generation of more critical voices ${ }^{2}$. Krisch appears to be referring to the latter camp when he mentions scholars who noted the decay of consent but have drawn from it an egalitarian picture, namely, a supposed "shift toward majoritarian decision making that retains for all states a right to equal participation." Krisch's vision is starker: "nonconsensualism, whether in formal or informal guise, creates more exclusive decision-making structures that reduce the number of decision makers - and typically not in an egalitarian fashion but in a way that entails a loss of control for all but the most powerful players."

While we are among those who have noted ${ }^{3}$ the democratic and egalitarian deficits entailed by the move to informal international lawmaking, we find ourselves less convinced by Krisch's misgivings concerning the decay of consent in a world dominated by a handful of powerful states. For better or worse, we believe that consent was never a major impediment to the dominant powerful states that could manipulate the global archipelago of treaty regimes to their benefit, relegating consent to a mere formal legitimating tool of submission to power. As Joseph Weiler has pointed out ${ }^{4}$, “the consent given by [most] 'sovereign' states is not much different to the 'consent' that each of us gives, when we upgrade the operating system of our computer

* Eyal Benvenisti is Anny and Paul Yanowicz Professor of Human Rights at Tel Aviv University Faculty of Law.

† George W. Downs is Bernhardt Denmark Professor of International Affairs and Professor of Politics at New York. University.

Originally published online 26 Mar. 2014.

${ }^{1}$ Nico Krisch, The Decay of Consent: International law in an Age of Global Public Goods, 108 AJIL 1 (2014).

2 JoOst PAUWELYN ET AL., INFORMAL INTERNATIONAL LAWMAKING (2012).

${ }^{3}$ Eyal Benvenisti \& George W. Downs, The Empire's New Clothes: Political Economy and the Fragmentation of International Law, 60 STAN. L. REV. 595 (2007).

${ }^{4}$ J.H.H. Weiler, The Geology of International Law - Governance, Democracy and Legitimacy, 64 Zeitschrift für ausländisches öffentliches Recht und Völkerrecht 547 (2004) (Ger.). 
and blithely click the 'I Agree' button on the Microsoft Terms and Conditions. One cannot afford to be out, and one cannot afford to leave."

If consent was a mere formality, it might indeed be worrisome that powerful states find it increasingly possible to eschew the need to obtain it and instead rudely force their policies on nonconsenting states. This practice by powerful states raises the specter of sidelining the basic notions of international law and state sovereignty. But Krisch does not make the simplistic argument that we need to keep the appearance of sovereignty and make an effort to retain formal institutions based on "consent", regardless of how it was obtained. Instead, he draws attention to a possible alternative to traditional consent, namely, "formalized procedures and participation rights," despite the fact that in his view, at this stage of development, these mechanisms still provide "only thin procedural compensations."

We suspect that the exposure of the decay of consent may operate to establish more effective protection against power than the decay of consent. As Krisch notes, the move to nonconsensualism has prompted efforts to seek procedural compensations that involve a variety of opportunities for voice and accountability of policymaking. As the emerging scholarship on global administrative law shows, even if these procedural obligations serve primarily to legitimize power, they also result in greater inclusion of disregarded interests. The inherently fragmented nature of international law has helped powerful states to obscure their domination and avoid accountability. But, as Krisch argues, the inevitable erosion of the mask has also forced powerful states to answer their detractors and provide reasons for their policies. Given that this is the case, his argument that "for most states, participation in [global decision-making] is far less effective than in classical multilateralism" remains unsubstantiated. The same is arguably true of his assertion that "[o]utside treaty making and formal international law, the notion of sovereign equality remains relatively weak."

We believe that the trajectory toward nonconsensualism should not be exaggerated or treated as a constant. Historically, reports about the death of international law are invariably premature. As Krisch has noted in a previous article ${ }^{5}$, the waxing and waning of international law are influenced to a large extent by the rise and fall of global hegemons. The current rise of nonconsensualism owes much of its strength to George W. Bush's policy ${ }^{6}$ of seeking the establishment of "results-oriented partnerships [that] emphasize international cooperation, not international bureaucracy[,] rely on voluntary adherence rather than binding treaties [and] are oriented towards action and results rather than legislation or rulemaking." Instead of inclusive bodies, the U.S. opted for" "coalitions of the willing [that] may be able to respond more quickly and creatively, at least in the short term" to global concerns.

But power still continues to shift. The G-8 found it useful to expand to the G-20, and even the most powerful states need to rely on concerted global action-embedded in formal treaties and institutions-to meet global challenges like deep sea mining and climate change. A declining hegemon is likely to embrace formal institutions to preserve its temporary power for as long as possible. It will, for example, seek to condition its promise of a military umbrella with economic concessions granted to it by client states. The current negotiations $^{8}$ over the Trans-Pacific Strategic Economic Partnership Agreement may reflect such dynamics where the consent of weaker countries is aggressively sought by the powerful. It is not at all clear that the weaker parties

${ }^{5}$ Nico Krisch, International Law in Times of Hegemony: Unequal Power and the Shaping of the International Legal Order, 16 EuR. J. INT'L L 369 (2005) and see also Paul B. Stephan, Symmetry and Selectivity: What Happens in International Law When the World Changes, 10 CHI. J. INT'L L. 91 (2009).

${ }^{6}$ National Security Council, The National Security Strategy: IX. Transform America's National Security Institutions to meet the Challenges and Opportunities of the 21st Century (2006).

${ }^{7}$ National Security Council, The National Security Strategy: X. Engage the Opportunities and Confront the Challenges of Globalization (2006).

8 Office of the United States Trade Representative, Trans-Pacific Partnership (2014). 
to these negotiations would be able to protect their citizens' interests against a powerful U.S. administration that seeks to enhance the protections of intellectual property and thereby render certain medicines inaccessible to many in the poorer countries. Also unclear is whether such an agreement would promote formalized procedures and participation rights or rather turn away from them. In other words, the accounts of Krisch and others focusing on the "stagnation" of international law" may accurately reflect recent trends, but counter trends continue to be evident and suggest that the future of international law will remain more open-ended than we imagine.

9 Joost Pauwelyn et al., When Structures Become Shackles: Stagnation and Dynamics in International Lawmaking, 25 EUR. J. INT'L L. 733 (2014).

ASIL and Eyal Benvenisti and George W. Downs (C) 2014 